\title{
Huiling Zhang
}

Uniwersytet Jagielloński w Krakowie

(iD) https://orcid.org/0000-0003-4997-0588

karolina.zhang@gmail.com

\section{JĘZYK I KULTURA POLSKA W OCZACH CHIŃSKIEJ MŁODZIEŻY AKADEMICKIEJ NA STUDIACH POLONISTYCZNYCH}

\section{POLISH LANGUAGE AND CULTURE IN THE EYES OF CHINESE ACADEMIC YOUTH OF POLISH STUDIES}

D0I: 10.24917/ycee.2020.11.93-99

$\begin{array}{ll}\text { Abstrakt: } & \text { Chiński projekt „Jeden pas i jeden szlak” wzmocnił współpracę pomiędzy Państwem Środka a Polską, co w ostatnich } \\ \text { latach wywołało na chińskich uczelniach ogromne zainteresowanie językiem i kulturą polską. Dzięki rozkwitowi studiów } \\ \text { polonistycznych na terenie Chin, nad Wisłę przyjeżdża coraz więcej chińskiej młodzieży akademickiej, która kształci } \\ \text { się na specjalistów do spraw relacji polsko-chińskich. Niniejsze badania o charakterze eksploracyjnym, zrealizowane } \\ \text { metodą wywiadu, stanowią próbę wstępnego zapoznania się z opiniami młodych chińskich polonistów o języku } \\ \text { i kulturze, których uczyli się podczas pobytu w sercu Europy. }\end{array}$

\section{Wstęp}

\a przestrzeni minionych lat można zaobserwować dynamiczny rozwój współpracy polsko-chińskiej w różnych dziedzinach, w tym także w sektorze edukacyjnym. Najlepiej świadczy o tym znaczący wzrost ośrodków studiów polonistycznych na terenie Chińskiej Republiki Ludowej. Wraz z rozkwitem języka i kultury polskiej w Państwie Środka zwiększa się grupa chińskiej młodzieży akademickiej na studiach polonistycznych w Polsce. Warto poświęcić uwagę 
młodym Chińczykom polonistom, którzy w przyszłości będą odgrywać istotną rolę w sprawach dotyczących relacji między oboma krajami.

W pierwszej części artykułu podaję definicję mlodzieży akademickiej będącej w centrum niniejszych badań. Kolejne dwie poświęcone są genezie próby badawczej, charakterystyce respondentów oraz metodzie, jaką zrealizowano projekt. Następnie prezentuję wyniki badań, które dzielą się na opinie badanych osób o języku polskim i o kulturze polskiej.

\section{Młodzież akademicka - definicja}

Zgodnie z definicją Światowej Organizacji Zdrowia (World Health Organization) wyraz youth, co odpowiada polskiemu słowu mtodzież, identyfikuje się z grupą wiekową od Is do 24 lat. W tym przedziale mieści się zdecydowana większosśc studentów studiów I stopnia pochodzących z Chińskiej Republiki Ludowej, gdzie maturzyści mający 17-19 lat po egzaminie dojrzałości zazwyczaj od razu wybierają się na studia (w Chinach uczeń rozpoczyna szkołę podstawową $\mathrm{w}$ wieku sześciu lub siedmiu lat, następnie spędza trzy lata w gimnazjum i tyle samo czasu w liceum). Dorosłość, mimo że na płaszczyźnie prawnej utożsamia się ją z pełnoletnością, z punktu widzenia rozwoju psychospołecznego różni się od dojrzałości. Tak jak podkreśliła Katarzyna Klimkowska, „osoba jest dorosła i jednocześnie dojrzewa do dorosłości. [...] Proces dojrzewania w dorosłości jest [...] szczególnie trudny dla młodych osób, które dopiero wkraczają w dorosłe życie, nie mają własnych doświadczeń z nim związanych, a w sferze psychospołecznej często dysponują przewagą cech specyficznych dla później adolescencji niż dorosłości. Do tej grupy należy młodzież akademicka" (Klimkowska, 2017, s. 70). W związku z powyższym termin mtodzież akademicka w niniejszej pracy oznacza osoby poniżej 24 roku życia o statusie studenckim.

\section{Geneza badań}

W roku 2013 przewodniczący Chin, Xi Jinping, przedstawił światu projekt pod hasłem "Jeden pas i jeden szlak” (tzw. „Nowy Szlak Jedwabny”) stanowiący istotną część nowej strategii otwarcia Państwa Środka. Koncepcja ta doprowadziła do intensywnej współpracy pomiędzy Chinami a krajami europejskimi w wielu dziedzinach, zwłaszcza gospodarczej i handlowej, co wywołało ogromne zapotrzebowanie na specjalistów znających języki i kultury tych krajów. Polska, dzięki swemu położeniu geograficznemu na styku Wschodu i Zachodu wyróżniła się spośród państw leżących na „Nowym Szlaku Jedwabnym”. Co więcej, zgodnie z wiadomościami Chińskiego Radia Międzynarodowego (China Radio International) od ponad dziesięciu lat Warszawa jest „największym partnerem handlowym Pekinu w regionie Europy Środkowo-Wschodniej" (Chińskie Radio Międzynarodowe, 2015b). W roku 20I5 prezydent Polski, Andrzej Duda, wybrał Państwo Środka jako kraj swojej pierwszej wizyty zagranicznej, a już rok później odbyła się oficjalna wizyta Xi w Polsce. Po odwiedzinach przywódców obu państw relacje polsko-chińskie weszły na poziom strategiczny. Osiągnięcie to wzbudziło znaczące zainteresowanie nauką polonoznawczą wśród chińskich uniwersytetów, szczególnie tych, w których przeważają kierunki filologiczne, zaczęto bowiem przewidywać na rynku pracy duży popyt na absolwentów ze znajomością języka polskiego i polskiej kultury. Stąd w Chinach dynamiczny rozwój studiów polonistycznych bądź polonoznawczych, jaki można zaobserwować na przestrzeni minionych lat. Według danych opublikowanych na stronie internetowej Instytutu Polski - Wydziału Kultury Ambasady Rzeczypospolitej Polskiej w Pekinie do maja 2020 roku na całym terenie Chińskiej Republiki Ludowej znalazło się w sumie 19 uniwersytetów, które oferowały możliwość nauki języka polskiego.

Rozkwit studiów polskich w Chinach niewątpliwie przyczynił się do intensywniejszej współpracy edukacyjnej między dwoma państwami. 
Najlepiej świadczy o tym rosnąca liczba studentów wysyłanych z chińskich uniwersyteckich ośrodków polonistycznych do Polski na krótkoterminowy kurs językowy, roczny staż języka i kultury polskiej czy dwuletnie studia polskie w ramach tzw. programu "podwójnego dyplomu” (przykład tego typu programu przedstawia artykuł Piotra Kajaka pt. Polish+. Program nowych studiów polskich na uniwersytecie syczuańskim $w$ Chengdu). Do chwili obecnej młodzi poloniści z Chin w trakcie studiów licencjackich, które w chińskim systemie oświatowym zazwyczaj trwają cztery lata, mogą pogłębić swoją wiedzę polonoznawczą na Uniwersytecie Jagiellońskim w Krakowie, Uniwersytecie Warszawskim, Uniwersytecie Gdańskim, Uniwersytecie Śląskim w Katowicach, Uniwersytecie Mikołaja Kopernika w Toruniu, Uniwersytecie im. Adama Mickiewicza w Poznaniu, Katolickim Uniwersytecie Lubelskim Jana Pawła II oraz Uniwersytecie Opolskim. Ze względu na to, że większość instytucji studiów polonistycznych w Państwie Środka prowadzi nabór studentów corocznie lub przynajmniej co dwa lata, grupa młodych Chińczyków uczących się języka polskiego jako obcego w kraju nad Wisłą będzie coraz liczniejsza.

W najbliższej przyszłości wzrośnie intensywność współpracy pomiędzy polskimi a chińskimi szkołami wyższymi. W związku z powyższym należałoby poświęcić więcej uwagi chińskiej młodzieży akademickiej, która zamieszkuje w Polsce, by kształcić się na ekspertów w dziedzinie języka polskiego i polskiej kultury. W porównaniu do innych chińskich studentów, którzy również studiują na polskich uczelniach, lecz w języku angielskim i na kierunkach niepolonistycznych, młodzi poloniści z Chin bez wątpienia mają większą szansę, aby po ukończeniu studiów odegrać istotną rolę w budowaniu długotrwałej i przyjaznej relacji polsko-chińskiej. Nie zabraknie wśród nich dyplomatów, konsultantów biznesowych, prawników, tłumaczy czy nauczycieli aktywnie działających w różnych obszarach dotyczących wzajemnych relacji między Polską a Chinami. Co więcej, dzięki swojej specyficznej kompetencji językowej oraz interkulturowej polonistyczna grupa chińskiej młodzieży akademickiej już w czasie własnej edukacji byłaby w stanie udzielać pomocy i wspierać swoich rówieśników-rodaków, którzy z powodu nieznajomości języka i kultury doznają na początku pobytu w Polsce szoku kulturowego. Ponadto mogliby oni również jako przedstawiciele wspólczesnego narodu chińskiego przybliżać Polakom kulturę swojego kraju. Mogą być więc zarówno ambasadorami Chin, jak też odegrać znaczącą rolę na rzecz Polski. Wymieniając ewentualne działania, jakie warto podjąć w celu podniesienia poziomu umiędzynarodowienia polskich uczelni, Marta Kaczmarek z Polish Academic Cooperation \& Exchange Foundation słusznie zaznaczyła: ,jeśli Polska realnie chce walczyć o kandydatów z Chin, [...]. Kluczowe wydaje się [...] monitorowanie losów tych cudzoziemców, którzy już w Polsce zdobywają wiedzę. Często to właśnie oni są później «ambasadorami» w polskiej sprawie" (Kaczmarek, 2013).

Na podstawie przedstawionych wyżej faktów zrodził się pomysł niniejszych badań, których celem jest rozpoznać specyficzną chińską grupę młodzieżową i narysować jej wstępny portret. W badaniach staram się zacząć od z pozoru banalnych, jednak zawsze interesujących dla polskich odbiorców pytań: jaki jest język polski i polska kultura w oczach chińskiej młodzieży akademickiej studiów polonistycznych, która przeżywa przygodę nad Wisłą?

\section{Charakterystyka badanej grupy oraz metoda badań}

Badania przeprowadzono wśród chińskiej młodzieży akademickiej przybyłej z trzech chińskich ośrodków polonistycznych na roczny kurs języka polskiego i polskiej kultury zorganizowany przez Centrum Języka i Kultury Polskiej w Świecie Uniwersytetu Jagiellońskiego w Krakowie w letnim semestrze roku akademickiego 2019/2020. Przebadana grupa składała się z siedmiu studentów z Pekińskiego Uniwersytetu Języków 
Obcych (Beijing Foreign Studies University), tyluż respondentów z Szanghajskiego Uniwersytetu Spraw Międzynarodowych (Shanghai International Studies University) oraz sześciu studentek z Kantońskiego Uniwersytetu Spraw Międzynarodowych (Guangdong University of Foreign Studies). W próbie badawczej przeważyła płeć żeńska (Is osób). Wiek badanych osób zamykał się w przedziale i 8-22 lat. Grupa pochodząca z uczelni pekińskiej była nieco młodsza niż pozostali respondenci i przed wyjazdem do Polski miała za sobą dopiero rok nauki języka polskiego, podczas gdy reszta badanej młodzieży studiowała w kraju polonistykę już dwa lata. W momencie przeprowadzenia ostatecznej próby badawczej większość, bo is badanych studentów, uczęszczała na kurs w grupie poziomu B2. Pozostałe osoby chodziły na zajęcia językowe dla poziomu BI.

Badania mają charakter jakościowy, gdyż zostały zrealizowane metodą wywiadu. Zorganizowano łącznie siedem dyskusji zbiorowych. W każdej z nich uczestniczyli respondenci pochodzący z tej samej uczelni macierzystej w Chinach. Były to badania fokusowe prowadzone za pomocą nowoczesnych technologii. Zamierzyłam przeprowadzić rozmowy z przebadaną młodzieżą twarzą w twarz, jednak z powodu nagle zaistniałej sytuacji epidemicznej musiałam zrezygnować $\mathrm{z}$ bezpośrednich kontaktów. Wywiady odbyły się zatem za pomocą chińskiego komunikatora internetowego WeChat $\mathrm{w}$ formie połączenia audialnego. Wszystkie dyskusje toczyły się w języku chińskim. Zostały one nagrane za zgodą uczestników, zapisane w formie pisemnej w programie Microsoft Word oraz przetłumaczone przeze mnie na język polski.

Badania mają charakter eksploracyjny i służą wstępnej znajomości poglądów chińskiej młodzieży akademickiej na studiach polonistycznych.

\section{Wyniki badań}

Pytania skierowane do przebadanych studentów zostały sformułowane w dosyć prosty sposób.
Brzmią one następująco: Jakim językiem jest język polski w Twoich oczach? oraz Jaka kultura jest kultura polska w Twoich oczach?

\section{O języku polskim}

Zacznijmy zatem od tego, jak chińska młodzież akademicka biorąca udział w badaniach postrzega język polski jako język obcy. Określenie, które najczęściej padało w dyskusjach, to bardzo trudny ${ }^{1}$. Jedna osoba stwierdziła, że polski jest trudniejszy niż wszystkie języki, z jakimi wcześniej obcowała, nie wymieniła jednak porównanych języków. Według innego rozmówcy polszczyzna może się wydawać łatwiejsza w zestawieniu z językiem arabskim, mimo że ogólnie jest bardziej wymagająca niż języki krajów zachodnioeuropejskich. W kolejnej grupie pytani respondenci również porównywali język polski z innymi językami europejskimi, lecz z perspektywy fonologicznej: „Myślę, że [polski] brzmi ładniej. Ładniej niż francuski, hiszpański i języki północnoeuropejskie”. Należałoby tu wspomnieć, że brzmienie polszczyzny cieszyło się uznaniem w kilku grupach dyskusyjnych. Nie zabrakło w wypowiedziach komentarzy wygłoszonych z perspektywy kilkunastoletniego doświadczenia w nauce języka angielskiego. Studentka z pekińskiej uczelni sądziła, że polski jest bardziej uporządkowany niż angielszczyzna, podczas gdy jej kolega polemizował z tym stwierdzeniem, zaznaczając, że w zestawieniu $\mathrm{z}$ językiem angielskim, który jego zdaniem jest zdecydowanie bardziej analityczny i logiczniejszy, to polszczyzna wydaje się chaotyczniejsza. Może być nieco zaskakujące, że tylko dwie osoby porównały polski ze swoim językiem ojczystym. Jedna z nich uważała, że „[polski] to jest język, który bardzo różni się od języka chińskiego", a druga zwróciła uwagę na to, że

W niniejszej pracy wszystkie wypowiedzi respondentów są od razu przytoczone w autorskim tłumaczeniu na język polski. 
nieraz trudno znaleźć chiński odpowiednik dla polskiego słowa.

Gramatyka polska została zgodnie przez przebadanych studentów uznana za skomplikowaną, lecz ściśle usystematyzowaną i bardzo logiczną, chociaż pojawiły się sprzeczne opinie co do logiczności języka polskiego. Jedna z nich została przytoczona wyżej. Druga, wygłoszona przez studentkę z Kantonu, zawiera konkretny przykład: „Jest dużo wyjątków. Niezwykle dużo wyjątkowych sytuacji. [...] Czasem też nie wydaje się do końca logiczny. Na przykład dzisiaj omówiono [słowo - przyp. red.] wnuk. Wnukowie oznacza tylko wnuków, a dopiero wnuki znaczy i wnuczki, i wnuków. Potem już nie wiem, co Polacy mają na myślii”. Język chiński jest językiem niefleksyjnym, dlatego deklinacja oraz koniugacja w języku polskim są zazwyczaj dla chińskojęzycznych uczących się ogromnym wyzwaniem. Jedna $z$ badanych studentek przyznała jednak, że zjawiska gramatyczne, które nie mają miejsca w jej języku ojczystym, są w sumie ciekawe, a czasami, dzięki różnorodnym odmianom, nawet zabawne. Inna osoba, opisując język polski pod względem gramatycznym, użyła wyrazu subtelny, który w języku chińskim przeważnie stosuje się przy opisie powierzchni lub dzieł sztuki, gdyż jej zdaniem mowa polska potrafi dostarczyć więcej informacji, dotyczących np. osób czy czasu, w pojedynczym tekście.

Obok gramatyki badani wymienili też inne trudności w nauce języka polskiego. Podczas wywiadów niejeden respondent narzekał, że Polacy mówią zbyt szybko. Określenie, którym także opisano polszczyznę to słowo maty, w sensie 'mało popularny' bądź 'posiadający niewielu użytkowników w skali globalnej'. Dwoje studentów w swoich odpowiedziach odnosiło się do kultury polskiej. Respondentka pochodząca z ośrodka w Szanghaju zauważyła, że niektóre słowa w języku polskim odzwierciedlają patriarchalność narodu polskiego. Podała dla przykładu wyraz pracowniczka: „Słowo to pochodzi z męskiej formy pracownik, dlatego mam wrażenie, że Polacy przywiązują większą wagę do mężczyzn". Pochodzący z Pekinu uczestnik dyskusji zadeklarował: „Język polski w moich oczach jest oczywiście ściśle powiązany z jego podłożem kulturowym, z całym jego narodem, szczególnie ze współczesną historią, w której naród ten najpierw został zgnębiony, a potem się zbuntowal”. Dzięki takiemu odniesieniu polszczyzna wydaje się respondentowi potężna i solidna. Kończąc pierwszą część omawiania wyników badań, chciatabym przytoczyć słowa będące również ostatnią wypowiedzią dotyczącą samego języka polskiego: „Myślę, że oprócz tego, że jest trudna, mowa ta jest dosyć wdzięczna".

\section{O kulturze polskiej}

Znamy już poglądy przebadanej grupy młodzieżowej z Chin na język polski, a jak odbiera ona polską kulturę? Większość respondentów zwróciła uwagę na dominującą w Polsce religię - katolicyzm. Podkreślili, że to jest jedna z najbardziej reprezentatywnych cech kultury polskiej. Niejedna osoba zauważyła, że wielu wierzących Polaków należy do Kościoła katolickiego, chodzi regularnie na mszę, w niedzielę zamyka sklepy i nie pracuje oraz że w miastach wszędzie stoją kościoły. Studentka z Pekinu zaznaczyła, że dzięki tak istotnej roli katolicyzmu kultura polska różni się od innych kultur słowiańskich. W dyskusjach pojawił się jednak także głos, jakoby dzisiaj Polacy już rzadko chodzą na mszę, dlatego respondent nie rozumiał znaczenia katolicyzmu w Polsce.

W wypowiedziach dosyć często wspominano tradycyjnie obchodzone nad Wisłą święta. Podtrzymywanie dawnych obyczajów świętowania stanowi dla części zapytanej młodzieży właściwy dowód na religijność poznawanej kultury, gdyż najistotniejsze polskie święta, jak np. Boże Narodzenie bądź Wielkanoc, są bezpośrednio związane z religią. Według innych fakt ten świadczy jednocześnie o tym, że Polacy są raczej konserwatywni i niezbyt otwarci. To nie 
był jednak jedyny portret Polaka, jaki kreowali uczestnicy wywiadów. Kantońska respondentka uważała, że kultura polska jest pół słowiańska, pół niemiecka, gdyż jej zdaniem Polacy lubią pić alkohol, czym cechują się także inne narody słowiańskie, ale jednocześnie są pracowici jak Niemcy i mniej leniwi niż Grecy czy Włosi. Porównanie z narodem włoskim pojawiło się również w wypowiedziach innej studentki, która stwierdziła, że po powrocie do Krakowa z wycieczki do Włoch miała wrażenie, jakoby kraj na Półwyspie Apenińskim jest dynamiczniejszy i energiczniejszy. Inny przymiotnik, jaki padł w kilku dyskusjach grupowych, to gościnny. Niemało uczestników badań uznało, że Polacy zasadniczo są bardzo życzliwi i otwarci wobec cudzoziemców, chętni do rozmowy z nimi. Chwalili także polskich kierowców, których uznali za grzecznych i kulturalnych, ponieważ na drogach zawsze ustępują pieszym. Wedle sondażu naród polski charakteryzuje się jeszcze ogromnym poczuciem dumy narodowej. Warto tu przytoczyć słowa studentki, które zyskały aprobatę całej grupy rozmówców: „Oni [Polacy] niezwykle doceniają osiągnięcia swojej kultury. W niezwykle dużym stopniu się z nią utożsamiają. Niezwykle ją lubią i podziwiają". Jedna z osób biorących w wywiadzie była pod wrażeniem dumy Polaków wobec własnej kultury: „Nie wyobrażałam sobie, jak państwo, które ma skomplikowaną historię i doświadczyło kiedyś zaborów, podchodzi do własnej kultury narodowej. Ale poprzez wcześniejsze uczestnictwo w szkole letniej i tegoroczny pobyt myślę, że większość obywateli Polski ma poczucie dumy wobec swojej kultury”.

Kolejne zagadnienie poruszane nieraz w wypowiedziach przebadanych młodych Chińczyków dotyczy literatury polskiej, która ich zachwyciła. Chodzi przede wszystkim o poezję. Uznano, że jest naprawdę piękna, a polscy poeci są wybitni i godni większej uwagi ze strony chińskich czytelników: „Myślę, że warto zbadać kulturę polską. Dużo ludzi zna tylko kulturę rosyjską i rosyjskie dzieła literackie, ale tak naprawdę w Polsce też jest wielu genialnych pisarzy". Studentka pochodząca z szanghajskiej uczelni odnosiła się do polskich wierszy w nieco komparatystyczny sposób: „W rzeczywistości pod pewnymi względami współczesna poezja polska i chińska mają ze sobą wiele wspólnego".

$\mathrm{Na}$ koniec relacji z wywiadów należałoby wspomnieć, że na drugie pytanie, w odróżnieniu od pierwszego, nie odpowiedzieli wszyscy respondenci biorący udział w dyskusji. Kilka osób z przebadanej grupy oświadczyło, że miało zbyt ograniczoną wiedzę o kulturze polskiej lub niewielki kontakt z Polakami w codziennym życiu, dlatego nie chciało zabierać głosu na ten temat.

\section{Podsumowanie}

Dzięki wprowadzeniu przez Państwo Środka projektu "Jednego pasa i jednego szlaku” w ostatnich latach można zaobserwować dynamiczny rozwój studiów polonistycznych na chińskich uniwersytetach. Oba kraje nawiązały szerszą współpracę w sektorze edukacji. Zwiększyła się także liczba chińskich studentów polonistyki na terenie Polski. Warto więc poświęcić więcej uwagi tej grupie młodzieży, która w przyszłości może stanowić most łączący oba kręgi kulturowe.

Niniejsze badania o charakterze eksploracyjnym przeprowadzone metodą wywiadu umożliwiają wstępne zaznajomienie się z poglądami chińskiej młodzieży akademickiej studiów polonistycznych języka i kultury polskiej. Okazało się, że przygodzie młodych polonistów Chińczyków z nauką języka polskiego towarzyszy wiele trudów, jednak udało im się znaleźć w niej przyjemność i dostrzec urodę polszczyzny. Opinie przebadanej grupy wobec kultury polskiej ogniskują się wokół religii, charakteru Polaków oraz literatury. Część respondentów nie udzieliła odpowiedzi na drugie pytanie $z$ powodu ograniczonej wiedzy o kulturze polskiej lub rzadkich kontaktów z Polakami. Należałoby zatem zastanowić się nad sposobami przybliżania chińskim studentom na 
studiach polonistycznych kultury Polski podczas ich pobytu nad Wisłą.

\section{Bibliografia}

Chińskie Radio Międzynarodowe (2015a). Jeden pas ijeden szlak. http:// polish.cri.cn/1364/2015/03/09/3415131746_1.htm [dostęp: 10.12.2020]

Chińskie Radio Międzynarodowe (2015b). Nowy rozdział współpracy między Chinami i Polska w ramach projektu "Jednego pasa i jednego szlaku" - Wizyta prezydenta Polski w Chinach. http://polish.cri. cn/1364/2015/12/25/415134220.htm [dostęp: 10.12.2020].

Chińskie Radio Międzynarodowe (2016). Przełomowa i historyczna wizyta Przewodniczacego Xi Jinpinga w Polsce. http://polish.cri. cn/1364/2016/06/23/3415135166.htm [dostęp: 10.12.2020].
Instytut Polski - Wydział Kultury Ambasady RP w Pekinie. Nauka polskiego w Chinach. https://instytutpolski.pl/beijing/pl/nauka-polskiego-w-chinach/ [dostęp: 18.10.2020].

Kaczmarek, M. (2013). Bój o chińskiego studenta. Forum Akademickie, 6. https://prenumeruj.forumakademickie.pl/fa/2013/06/boj-0-chinskiego-studenta/ [dostęp: 13.03.2021].

Kajak, P. (2020). Polish+. Program nowych studentów polskich na Uniwersytecie Syczuańskim w Chengdu. Poradnik Językowy, 3, s. 69-82.

Klimkowska, K. (2016). Wspieranie młodzieży akademickiej w dojrzewaniu do dorosłości. Kultura i Wartości, 18, s. 69-86.

Światowa Organizacja Zdrowia (2021). Adolescent health in the South-East Asia Region. https://www.who.int/southeastasia/health-topics/ adolescent-health\# [dostęp: 13.03.2021]. 